\title{
MEMBACA KILAS REGULASI PEREKONOMIAN DI INDONESIA DAN MENAKAR PERAN PERBANKAN SYARIAH
}

\author{
Selamet Syaifuddin, M.Ag., M.Pd. \\ Peneliti el KASYF Kudus
}

\begin{abstract}
Abstrac
The New Order era was a time of great economic decline. Faced with the problem, the New Order government took a strategic and pragmatic step, namely with the development of the economy oriented abroad. This orientation is intended for foreign investors to enter and invest their shares in Indonesia. This policy has had a positive impact on Indonesia's economic development with the entry of foreign investors to Indonesia, especially Japan and Europe. The declining Indonesian economy, the legacy of the Old Order can be overcome. Such an overseas-oriented development strategy is supported by the surge in oil prices in the international market or known as the oil and gas boom era in the period 19731982.

It is no exaggeration if the factors: foreign aid and foreign exchange from oil and gas (oil and gas) are two of the most supportive factors in overcoming the Indonesian economy. These two factors contribute the most to national development funds. However, dependence on foreign aid as a source of development funds can no longer be a major backdrop in line with the world economic recession that occurred in the early 1980s. Of course, the world economic recession has had a huge impact on Indonesia's donor countries. The deteriorating economic condition of those affected by aid funds is being donated to recipient countries, including Indonesia.
\end{abstract}

Keywords: Regulation, Economy, Syariah Banking

\section{A. Pendahuluan}

Resesi ekonomi dunia diawali dengan kelesuan ekonomi Amerika Serikat yang disebabkan membengkaknya anggaran belanja tahunan Amerika Serikat sehingga menimbulkan pembengkakan harga (Nasution, 1994:63). Guna menutupi defisit anggaran tersebut, pemerintah mengeluarkan kebijakan dengan mengeluarkan obligasi (Kara, 2005: 128). Akibatnya, terjadi kenaikan tingkat suku bunga sehingga mendorong aliran modal masuk ke Amerika Serikat.

Implikasinya adalah terjadinya inflasi, daya saing produksi melemah sehingga ekspor negara itu turun, sementara impor mengalami kenaikan yang signifikan. Terkait dengan valuta asing, mata uang Amerika Serikat, mengalami depresiasi terhadap yen, mata uang Jepang. Semuanya berakhir dengan 
Selamet Syaifuddin

melemahnya struktur ekonomi Amerika Serikat, dan tentu saja berimbas pada negara-negara di dunia. Sebab banyaknya penggunaan Dollar Amerika Serikat dalam transaksi ekonomi. Indonesia sendiri mengalami peningkatan utang luar negeri sekitar 30\% akibat depresiasi dollar terhadap yen (Kara, 2005:129).

Kondisi perekonomian dunia di atas, diperparah lagi dengan merosotnya harga minyak bumi di pasaran Internasional. Padahal devisa dari sektor ini memberi sumbangan terbesar terhadap pendapatan dalam negeri bagi dana pembangunan nasional. Sebagai salah satu negara penghasil minyak, tentu Indonesia sangat bergantung pada pendapatan dari sektor tersebut. Menghadapi kondisi demikian, pemerintah orde baru pada awal dekade 1980-an mengeluarkan beberapa kebijakan ekonomi, paling tidak, mengurangi ketergantungan pada dana bantuan luar negeri bagi kesinambungan pembangunan nasional. Kebijakan itu diambil agar pembangunan yang sudah dijalankan dapat dijaga kesinambungannya.

Pemerintah menganggap pemanfaatan potensi dan kekuatan ekonomi yang berbasis dalam negeri merupakan suatu pilihan yang tepat untuk mengurangi ketergantungan pada bantuan luar negeri. Maka sejak tahun 1983, pemerintah mengeluarkan beberapa kebijakan yang intinya menarik dana-dana yang ada dalam masyarakat agar disimpan pada lembaga-lembaga perekonomian, baik pemerintah maupun swasta. Dana-dana tersebut dapat dimanfaatkan bagi pembangunan nasional.

\section{B. Pembahasan}

\section{Penentuan Langkah Membangun Ekonomi}

Pada bulan Juni 1983, pemerintah mengeluarkan paket deregulasi di sektor perbankan yang memberi kewenangan kepada bank-bank nasional dan bank campuran untuk menentukan sendiri tingkat suku bunga (Perwataatmaja, 1996: 31). Keluarnya paket tersebut menempatkan pemerintah melalui Bank Indonesia tidak terlalu jauh mencampuri tingkat suku bunga yang ditetapkan suatu bank kepada para nasabahnya.

Memang dalam Undang-Undang No. 14 tahun 1967 tidak disebutkan secara tegas tingkat bunga yang ditetapkan pemerintah bagi suatu lembaga 
perbankan, namun dalam praktiknya, peran pemerintah sebagai pengawas dan pembina bagi lembaga perbankan untuk menentukan tingkat suku bunga begitu dominan. Hal itu ditandai dengan adanya ketentuan pemerintah mengenai tingkat suku bunga yang harus dilaksanakan oleh bank.

Paket deregulasi perbankan Juni 1983 menjadi dasar bagi bank untuk menentukan tingkat suku bunga yang sesuai dengan kondisi banknya masingmasing. Dengan ketentuan itu, antara satu bank dengan bank lainnya akan berbeda dalam menentukan tingkat suku bunganya. Dengan ketentuan itu pula, pemerintah mengharapkan agar perbankan nasional dapat lebih agresif dalam menarik minat masyarakat agar mau menginvestasikan dananya pada bank dengan cara menentukan bunga yang menarik perhatian para calon nasabah. Sebab secara teoritis, semakin tinggi tingkat bunga semakin menarik perhatian calon nasabah menabung uangnya.

Pada sisi lain, kebijakan deregulasi perbankan Juni 1983, dapat menjadi dasar bagi dunia perbankan untuk menerapkan tingkat bunga 0\%. Atau dengan kata lain, bank dapat melakukan transaksi ekonomi tanpa menerapkan sistem bunga yang dalam pandangan ekonomi Islam tidak dibenarkan. Sebenarnya paket itu juga memberi peluang bagi pendirian bank Islam, namun pendirian bank baru pada saat itu tidak mendapat izin dari pemerintah.

Setelah diberlakukannya paket Juni 1983, pemerintah memandang perlu mengeluarkan kebijakan baru yang lebih memberi peluang kepada dunia perbankan untuk menarik dana dari masyarakat. Paket Juni 1983 dinilai belum cukup, sebab beberapa hal penting seperti pendirian bank baru belum diatur. Maka pemerintah mengeluarkan kebijakan baru di bidang keuangan, moneter dan perbankan, yaitu kebijakan paket 27 Oktober 1988, lebih dikenal dengan pakto 1988

Dalam perundang undangan paket kebijakan keuangan, moneter dan perankan menyebutkan kebijakan di bidang keuangan, moneter dan perbankan tersebut bertujuan untuk pengerahan dana masyarakat, peningkatan ekspor non migas, peningkatan efisiensi, peningkatan kemampuan pelaksanaan kebijakan moneter, dan iklim pengembangan pasar modal. Semuanya bermuara terjadinya Bisnis Vol 6, No.1, Juni 2018 


\section{Selamet Syaifuddin}

peningkatan pendapatan negara dari dalam negeri. Pengerahan dana masyarakat yang merupakan salah satu prioritas penting pemerintah dalam pakto 1988, pemerintah mengeluarkan beberapa kebijakan mendasar. Di antara kebijakan itu: kebijakan tentang pembukaan kantor cabang bank, baik kantor cabang bank pemerintah, bank pembangunan daerah, bank swasta nasional, dan bank koperasi, kebijakan pembukaan cabang Lembaga Keuangan Bukan Bank (LKBB), pendirian bank swasta pendirian, dan usaha Bank Perkreditan Rakyat, penerbitan sertifikat deposito, dan perluasan tabungan..

Kemudahan membuka kantor cabang dan pendirian bank baru merupakan hal penting dalam dunia perbankan di Indonesia. Sebab Undang-Undang No. 14 tahun 1967 tentang Pokok-Pokok Perbankan walaupun mengatur hal-hal yang berkaitan dengan pendirian bank dan pembukaan kantor cabang, namun pemerintah sulit memberi perizinan, terutama untuk bank-bank swasta. Dalam pasal 5 Undang- Undang No. 14 tahun 1967 disebutkan bahwa bank umum milik negara didirikan dengan undang-undang berdasarkan ketentuan-ketentuan dalam undang-undang ini. Sedangkan pembukaan kantor cabang dan perwakilan dari bank umum milik negara hanya dapat dilakukan dengan izin Menteri Keuangan setelah mendengar pertimbangan Bank Indonesia. Sementara itu, pendirian bank umum swasta menurut UU nomer 14 tahun 1967 harus memnuhi syarat sebagai berikut:

a. Berbentuk hukum perseroan terbatas

b. Mempunyai modal yang telah dibayar sekurang-kurangnya Rp. 1.000.000,(Menteri Keuangan dapat menetapkan jumlah modal dibayar minimum yang lebih tinggi menurut perkembangan keadaan dengan memperhatikan kondisi setempat.

c. Saham-saham dari perseroan terbatas seluruhnya harus dimiliki oleh wargawarga Indonesia dan atau badan-badan hukum peserta-pesertanya dan pimpinannya terdiri atas warga negara Indonesia, menurut syarat-syarat yang ditetapkan oleh Menteri Keuangan.

d. Pimpinan dan pegawai dari bank yang mempunyai kedudukan vital harus seluruhnya warga negara Indonesia. 
Kesulitan mendirikan bank baru sebagaimana yang disyaratkan di atas dijelaskan kembali pada penjelasan pasal 8 tersebut. Di samping syarat-syarat mengenai permodalan, pemilikan saham dan pimpinan/pegawai bank, Menteri Keuangan mempunyai wewenang untuk jika perlu menetapkan syarat-syarat tambahan, antara lain dalam hubungannya dengan kehendak riil dan urgensi dari pendirian suatu bank pada suatu tempat/daerah menurut kondisi sosial-ekonomis dari tempat/daerah yang bersangkutan.

Syarat-syarat tambahan itulah membuat para pemilik modal mengalami kesulitan untuk mendirikan bank baru dan berinvestasi dalam dunia perbankan. Syarat tambahan itu berkaitan dengan kusutnya sistem birokrasi di Indonesia. Apalagi bagi para pengusaha yang tidak terlalu mempunyai modal yang cukup atau jaringan birokrasi akan mengalami kesulitan untuk mendirikan sebuah bank baru.

Dengan lahirnya pakto 1988 yang memberi kemudahan mendirikan kantor cabang dan bank umum baru, sejak itu perbankan Indonesia mengalami perkembangan kuantitasnya. Jumlah bank mengalami perkembangan yang cukup pesat, tentu saja menambah dana bagi pembangunan nasional. Pakto 1988 memberi harapan besar bagi pendirian bank umum Islam di Indonesia, walaupun realisasi pendirian itu dapat dilakukan pada tahun 1991, dengan berdirinya Bank Muamalat Indonesia. Namun demikian, pakto 1988 memberi semangat kepada umat Islam untuk mendirikan bank-bank Islam yang berskala kecil, seperti Bank Perkreditan Rakyat. Bank-bank tersebut cukup memberi andil bagi penghimpunan dana masyarakat untuk pembangunan nasional. Sebab sebagian umat Islam yang menganggap bunga uang sebagai riba dapat menyalurkan pandangan keagamaannya kepada BPR yang menerapkan bunga $0 \%$ tersebut.

Kondisi BPR yang beroperasi dengan prinsip syari'ah yang belum ada payung hukumnya, mengatur tata cara penerapan sistem syari'ah dalam operasional perbankan Islam, mendorong pemerintah Indonesia melakukan kebijakan hukum yang lebih jauh dalam masalah perbankan Islam di Indonesia. Kondisi tersebut diperkuat lagi dengan keberadaan Bank Muamalat Indonesia yang didirikan pada tahun 1992, bertepatan dengan pembahasan Rancangan Bisnis Vol 6, No.1, Juni 2018 
Selamet Syaifuddin

Undang-Undang No. 7 Tahun 1992 tentang Perbankan Nasional di DPR. Keberadaan Bank Muamalat Indonesia yang didirikan umat Islam dan mendapat respons positif dari penguasa Orde Baru, khususnya presiden Soeharto, mempunyai pengaruh yang cukup signifikans diakomodasinya prinsip syari'ah. Maka pada tahun 1992 melalui Undang-Undang No. 7 tahun 1992 tentang Perbankan, diakomodasi ketentuan-ketentuan yang mengatur operasional bank yang beroperasi dengan sistem syari'ah. Walaupun undang-undang itu sendiri belum secara eksplisit menyebut bank syari'ah, tapi bank dengan prinsip bagi hasil.

Secara ekonomis keberadaan bank-bank Islam akan menguntungkan pemerintah Indonesia karena sebagai umat yang mayoritas memiliki potensi ekonomi yang besar untuk pembangunan bangsa. Sebagian dari mereka menganggap bunga termasuk dalam kategori perbuatan riba, sehingga mereka tidak mau menginvestasikan dananya pada bank-bank konvensional. Kehadiran bank Islam akan memberi peluang kepada mereka untuk menabung, dan dengan sendirinya akan meningkatkan pendapatan negara dalam sektor pendapatan dalam negeri.

\section{Krisis Ekonomi dan Posisi Perbankan Syari'ah Indonesia.}

Krisis ekonomi yang melanda perekonomian bangsa Indonesia menimbulkan berbagai efek dalam kehidupan bangsa ini, tidak hanya dalam kehidupan ekonomi, tapi juga menimbulkan krisis yang berkepanjangan dalam bidang politik dan sosial masyarakat. Krisis tersebut memaksa para elit politik bangsa Indonesia melakukan berbagai reformasi ekonomi dan politik. Kebijakankebijakan ekonomi lebih diarahkan bagaimana masyarakat Indonesia bisa keluar dari krisis tersebut dengan melakukan berbagai macam cara dan metode yang ada.

Krisis ekonomi tersebut merupakan rangkaian dari krisis yang melanda beberapa negara di Asia, khususnya negara-negara Asia Tenggara. Krisis ekonomi negara-negara Asia berawal dari gejolak terjadi di pasar uang yang terjadi di Thailand pada awal bulan Juli 1997(Djiwandono, 2001: 9). 
Krisis yang terjadi di Thailand merupakan kepanikan keuangan Thailand yang ditimbulkan karena perubahan sentimen pasar terhadap perekonomian negara tersebut. Kepanikan keuangan itu dimulai dengan para kreditor dan investor menghentikan dana masuk dan menggantinya dengan gerakan penarikan dana yang mereka investasikan sehingga menekan nilai tukar mata uang baht, mata uang Thailand, terhadap dollar Amerika Serikat. Gejolak itu disikapi pemerintah Thailand dengan mengubah sistem nilai tukar mata uang bath, dari sistem nilai tukar tetap menjadi mengambang pada tanggal 2 Juli 1997.

Krisis yang melanda Thailand dengan cepat merambah negara-negara lain di Asia seperti Korea Selatan, Filipina, Malaysia, dan termasuk negara Indonesia pada pertengahan bulan Juli tahun 1997. Indonesia adalah salah satu negara yang masih dilanda krisis ekonomi sampai sekarang.

Terhadap krisis di negara-negara Asia, para pakar ekonomi melakukan berbagai analisa terhadap faktor-faktor yang melatarbelakangi timbulnya krisis tersebut. Paling tidak, ada dua argumen yang diajukan para pakar ekonomi, yaitu faktor eksternal dan faktor internal (Djiwandono, 2001: 10). Analisis pertama misalnya dilakukan oleh Charles P. Kindleberger, menegaskan bahwa krisis Asia terjadi akibat perubahan pasar uang secara cepat yang menimbulkan kepanikan finansial. Selanjutnya kepanikan finansial ini melalui proses penularan menjadi krisis. Analisis kedua mengajukan argumen bahwa krisis di negara-negara Asia timbul karena adanya kelemahan struktural di dalam perekonomian nasional, baik dalam sistem perbankan maupun lembaga keuangan lainnya. Di samping itu, krisis ekonomi terjadi karena adanya praktik kapitalisme kroni dalam perekonomian di negara-negara Asia. Analisis ini dilakukan, antara lain oleh Kunia Yoshihara. Para pakar yang mempunyai argumen pertama, oleh Stephen Haggard di kenal dengan internationalist, sedangkan kelompok kedua, dikenal dengan fundamentalist.

Penilaian serupa dikemukakan Sarkaniputra (2011), bahwa globalisasi menurutnya mungkin dapat dinilai sebagai bentuk penjajahan versi baru. Sebab sektor swasta di negara-negara maju begitu dominan sehingga mereka dapat "memaksa" pemerintahannya melakukan ekspansi di negara-negara lain, Bisnis Vol 6, No.1, Juni 2018 


\section{Selamet Syaifuddin}

khususnya negara-negara berkembang; di samping memaksimalkan peran lembaga keuangan dan perbankan yang mereka kuasai seperti IMF, World Bank dan lainnya. Bagi Sarkaniputra, ada tidaknya krisis ekonomi di Indonesia, masyarakat Indonesia tetap memikul beban utang yang begitu berat karena terjebak dalam arus globalisasi ekonomi yang dikuasai oleh negara-negara maju. Sementara penjadwalan utang terkait dengan kepentingan politik, ekonomi dan militer yang hanya mementingkan bagi perusahaan dan negara kreditor.

Dalam konteks krisis yang dialami Indonesia tersebut, menurut J. Soedradjat Djiwandono(2001:11) bukan hanya disebabkan oleh kepanikan keuangan sebagaimana gambaran yang dikemukakan kelompok internationalist, dan sebaliknya bukan hanya semata-mata disebabkan oleh merajalelanya kapitalisme kroni dan permasalahan struktur ekonomi. Akan tetapi, menurutnya disebabkan oleh kombinasi kedua faktor tersebut yang bekerja secara bersamaan, yaitu unsur eksternal berupa kepanikan keuangan dan lemahnya sistem perekonomian nasional, baik dalam sektor perbankan maupun sektor riil. Kelemahan struktur ekonomi nasional menyebab lemahnya daya tahan perekonomian menghadapi krisis yang terjadi.

Sejalan dengan pemikiran J. Soedradjat Djiwandono, Bank Indonesia dalam laporan tahunannya 1997/1998 mengakui bahwa krisis yang terjadi di Indonesia disebabkan karena akibat dari semakin cepatnya proses integrasi perekonomian Indonesia ke dalam perekonomian global. Sementara pada saat yang sama perangkat kelembagaan perekonomian yang memungkinkan bekerjanya ekonomi pasar yang efisien belum tertata dengan baik, bahkan perangkat-perangkat itu belum ada.

Krisis tersebut telah menyebabkan terpuruknya berbagai indikator ekonomi makro. Pada tahun 1998 laju inflasi mencapai 78\%, bahkan mencapai angka $100 \%$ pertengahan tahun 1999, padahal tahun-tahun sebelumnya, selalu di bawah $10 \%$. Sedangkan pertumbuhan ekonomi Indonesia yang mantap dengan tingkat pertumbuhan rata rata-rata $7 \%$ per tahun sebelum krisis; akan tetapi, setelah masuk dalam krisis ekonomi (1998) anjlok dengan minus $15 \%$. Dalam laporan tahunan 1998 menyebutkan Kenaikan tingkat suku bunga yang begitu 
tinggi, dari rata-rata $20 \%$ menjadi $70 \%$ per tahun. Krisis itu pula menyebabkan membengkaknya utang luar negeri Indonesia seiring menguatnya nilai tukar dollar Amerika Serikat terhadap rupiah.

Akibatnya, biaya hidup dan biaya produksi melonjak dengan tajam seiring dengan kenaikan harga-harga barang. Tingkat pengangguran mencapai 20 juta jiwa, dan tingkat kemiskinan absolut yang melonjak tajam mencapai lebih dari separuh penduduk Indonesia pada tahun 1999 (Indrawati, 1999: 2). Lonjakan kemiskinan itu disebabkan karena merosotnya daya beli masyarakat.

Selain melemahkan indikator ekonomi di atas, krisis eknomi juga menyebabkan hancurnya berbagai institusi vital ekonomi yang menjadi penentu dari berbagai aktifitas ekonomi dan bahkan sebagai institusi bagi pemulihan krisis ekonomi itu sendiri. Institusi-institusi seperti: perbankan, jalur distribusi, kelangsungan hidup korporat (baik besar, menengah maupun kecil) yang menjadi mesin produksi ekonomi, serta terganggunya mekanisme pasar(Indrawati, 1999: 2).

Perbankan merupakan institusi ekonomi Indonesia yang paling besar terkena imbasnya dari krisis ekonomi yang terjadi, tanpa menafikkan institusi lainnya. Hal itu memang wajar, sebab krisis ekonomi di Indonesia dan negaranegara Asia lainnya merupakan krisis yang diawali dari dunia perbankan. Akibatnya, banyak bank baik bank pemerintah maupun swasta yang mengalami kekurangan likuiditas yang menyebabkan beberapa bank diambil alih oleh pemerintah dan bahkan ditutup operasionalnya.

Petaka bagi dunia perbankan di Indonesia terjadi pada tanggal 1 November 1997, tiga setengah bulan ditimpa krisis moneter. Melalui Menteri Keuangan, Mar'ie Muhammad, pemerintah mengumumkan pencabutan izin operasional 16 bank umum. Pencabutan itu sebagai bagian dari usaha pemerintah dalam upaya penyehatan perbankan nasional (----, 1997: 7). Pengumuman itu merupakan rangkaian pertama pencabutan izin operasional perbankan nasional dari beberapa rangkaian selanjutnya.

Pemerintah melalui Menteri Keuangan, mengemukakan bahwa pencabutan izin usaha bank-bank tersebut disebabkan beberapa kriteria, antara lain: 
Selamet Syaifuddin

Pertama, aset yang dimiliki tidak cukup untuk menutup kewajibannya. Hal itu disebabkan karena besarnya kredit macet. Kedua, akibat besarnya kredit macet, maka penghasilan yang diperoleh bank tidak bisa menutupi biaya-biaya yang dikeluarkannya. Hal ini menimbulkan kerugian yang kemudian dari tahun ke tahun semakin besar. Ketiga, kemampuan bank untuk menghimpun dana masyarakat semakin berkurang, sehingga sumber pendanaan bank banyak tergantung pada pasar uang antar bank yang berjangka pendek dan berbunga tinggi. Keempat, karena akumulasi kerugian yang semakin besar, mengakibatkan modal menjadi negatif.

Kondisi yang berbeda terjadi pada Bank Muamalat Indonesia, sebagai satu-satunya bank umum yang beroperasi sesuai dengan sistem syari'ah Islam yang tidak menggunakan bunga bank sebagai konsep dasar operasionalnya. Walaupun Bank Muamalat Indonesia merupakan bank yang menggunakan pola bagi hasil, dalam sebagian kalangan masyarakat Indonesia dianggapnya sebagai sistem yang tergolong 'baru' dan bahkan tidak berlebihan bila disebut 'asing' dapat bertahan dari krisis moneter yang terjadi.

Berdasarkan laporan tahunan Bank Muamalat Indonesia tahun 1998, Bank Muamalat merupakan bank yang tidak mengalami negative spread, sebagaimana yang terjadi di beberapa bank konvensional. Ini tidak berarti bank yang beroperasi sesuai syari'ah ini tidak mengalami kesulitan dalam masa krisis tersebut, paling tidak ia mampu bertahan dan mampu mencapai pertumbuhan yang positif, laporan 1998 memperlihatkan dari tingkat pertumbuhan pada tahun 1996 rata-rata 40\%, walaupun pada akhir tahun 1997 , pertumbuhannya hanya $18 \%$.

Perkembangan sumber dana tabungan mudharabah, terjadi pertumbuhan yang positif dari tahun ke tahun. Peningkatan terbesar terjadi pada tahun 1998 dimana nilai pertumbuhan pada tahun itu adalah sebesar 53,4\% atau meningkat dari Rp 14,9 milyar pada tahun 1997 meningkat menjadi Rp 22,9 milyar pada tahun 1998. Dengan nilai rata-rata pertumbuhan/tahun untuk jenis produk tabungan mudharabah adalah sebesar 26,7 persen

Salah satu prestasi yang perlu diakui adalah kemampuan bank yang beroperasi dengan sistem syari'ah ini mempertahankan rasio kesehatan bank di 
tengah krisis yang melanda perbankan konvensional. Laporan 1998 Bank Muamalat pada tahun 1998 mampu mempertahankan modal CAR (rasio kecukupan modal)nya pada tingkat sehat yakni $6,76 \%$.

Memang harus diakui bila dilihat dari kinerja keuangan Bank Muamalat Indonesia pada tahun 1998 terjadi penurunan pada tingkat pendapatan laba dan bahkan mengalami kerugian. Bila dibandingkan dengan tahun 1997 yang membekukan pendapat bersih sebesar Rp.7,410 miliar atau Rp.49 persaham, maka pada tahun 1998 Bank Muamalat justru mengalami kerugian Rp. 106,983 miliar atau Rp. 884 per saham. Namun demikian, bila dilihat dari rata-rata perbankan nasional, apa yang diraih oleh bank Muamalat tersebut masih lebih baik, karena pendapatan dari pos marjin dan bagi hasil tetap positif yaitu sebesar Rp. 2,557 miliar. Dengan demikian, tingkat Bank Muamalat Indonesia masih dapat memperoleh pendapatan bersih dari pos pembiayaan sebesar $0,55 \%$ dari total dana yang disalurkan. Perolehan ini jauh lebih baik dibandingkan dengan bank swasta yang beroperasi dengan sistem bunga yang mengalami kerugian sebesar $13,63 \%$ pada tahun yang sama (laporan 1998). Walaupun harus diakui bahwa dana yang beredar dalam Bank Muamalat Indonesia jauh lebih kecil dari jumlah dana yang beredar di berbagai perbankan nasional, yakni 0,01\%(Kara, 140).

Ini menunjukkan bahwa perbankan yang menggunakan sistem tanpa bunga mempunyai landasan ekonomi yang kuat dari serangan krisis keuangan yang terjadi. Kenyataan ini menambah keyakinan atas pendapat sebagian kalangan, terutama para pelaku dan pendukung ekonomi Islam bahwa sistem perbankan non bunga tidak mudah digoyahkan oleh krisis keuangan akibat spekulasi. Karena sistem ini menitikberatkan pada sektor riil sebagai lahan investasinya.

Kritikan terhadap pemberlakuan tingkat suku bunga yang tinggi dan hubungan dengan kenaikan tingkat inflasi yang terjadi di Indonesia, sebenarnya sebelum masa krisis yang terjadi pada pertengahan bulan Juli 1997, pernah dilontarkan oleh B.J Habibie. Sewaktu menjabat Menteri Negara Riset dan Teknologi (Menristek), Habibie mengatakan bahwa tingkat bunga itu mempengaruhi tingkat inflasi. Penurunan tingkat bunga secara bertahap dan dengan cara zig-zag, dalam jangka waktu panjang akan menurunkan tingkat Bisnis Vol 6, No.1, Juni 2018 
Selamet Syaifuddin

inflasi (rahardjo, 1999 16): Pandangan ini secara cepat menjadi hangat perdebatan publik karena tidak lazim dalam pandangan para ekonom, terutama kelompok ekonom "Barkeley" yang menjadi pilar ekonomi Orde Baru.

Habibie mengkritik kebijakan dan praktik perbankan di Indonesia yang menaikkan suku bunga yang tinggi yang menyebabkan terhambatnya kegiatan produksi. Dengan turunnya suku bunga menurut Habibie akan menggairahkan pasar modal karena kegiatan produksi akan lebih bergairah seiring dengan turunnya tingkat suku bunga. Pandangan ini ditolak oleh ekonom yang mengatakan bahwa tingkat suku bunga bukan merupakan persoalan pokok dalam menggairahkan produksi karena bunga bukan bagian dari ongkos produksi. Justru yang menjadikan kegiatan tidak efisien adalah terjadinya berbagai pungutan liar yang sebenarnya tidak perlu terjadi.

Kritikan terhadap sistem bunga semakin menggema ketika bangsa-bangsa Asia Tenggara mengalami krisis keuangan. Bahkan Mahathir Muhammad, Perdana Menteri Malaysia dalam seminar IMF- Bank Dunia di Hongkong 25 September 1997, menuduh George Soros, pemilik Quantum Fund Management, sebagai biang dari krisis ekonomi yang terjadi di negara-negara Asia Tenggara, karena ulahnya dalam melakukan spekulasi terhadap mata uang di Thailand.

Akibat praktik spekulasi tersebut menimbulkan penilaian dari Mahathir bahwa perdagangan mata uang itu adalah kegiatan yang tidak perlu dilakukan (unnecessary), tidak produktif (unproductive) dan lebih dari itu, perdagangan uang merupakan perbuatan yang tidak bermoral (immoral) (Rahadjo, 1999: 18). Dengan pertimbangan tiga aspek tersebut, Mahathir Muhammad menyerukan agar perdagangan keuangan ditiadakan karena akan mengundang para spekulan menarik keuntungan jika kondisi keuangan suatu negara melemah. Namun demikian, seruan Mahathir ini tidak dijalankan secara utuh oleh pemerintah Malaysia sendiri karena masih beroperasinya sistem perbankan konvensional di negara tersebut.

Seruan Mahathir itu juga dapat berimplikasi lebih menggairahkan para pelaku ekonomi dan pemerintah baik dunia Islam maupun negara-negara yang ingin menerapkan sistem non bunga dalam praktik perbankan mereka. Sehingga 
para elite politik itu dalam merumuskan kebijakan ekonominya, khususnya dunia perbankan, aspek perdagangan uang dan sistem bunga menjadi perhatiannya dalam rangka mencari alternatif untuk keluar dari krisis ekonomi yang melanda negerinya.

Apalagi kasus seperti di Indonesia di mana bank-bank konvensional begitu rapuh terhadap "serangan' kaum spekulan maka pencarian sistem alternatif begitu diperlukan dalam rangka recovery ekonomi. Tentu saja didukung oleh aspek lain, seperti kemauan politik (political will) pemerintah.

\section{Kesimpulan}

Profile perbankan syari'ah akan tampak bila di antaranya ditelusuri dari sudut lahirnya Undang-Undang No.10 tahun 1998. Terbitnya undang-undang ini memiliki hikmah tersendiri bagi dunia perbankan nasional di mana pemerintah membuka lebar kegiatan usaha perbankan dengan berdasarkan pada prinsip syari'ah. Hal ini guna menampung aspirasi dan kebutuhan yang berkembang di masyarakat. Masyarakat diberikan kesempatan seluas-luasnya untuk mendirikan bank berdasarkan prinsip Bank Syari'ah ini, termasuk juga kesempatan konversi dari bank umum yang kegiatan usahanya berdasarkan pada pola konvensional menjadi pola syari'ah. Selain itu dibolehkan pula bagi pengelola bank umum konvensional untuk membuka kantor cabang atau mengganti kantor cabang yang sudah ada menjadi kantor cabang khusus syari'ah dengan persyaratan yang tentunya melarang pada percampuran modal kerja dan akuntansinya.

Prospek perbankan syari'ah, kalau dilihat secara makro ekonomi, pengembangan bank syari'ah di indonesia memiliki peluang besar karena peluang pasarnya yang luas sejurus dengan mayoritas penduduk negeri ini. UndangUndang Nomor 10 tahun 1998 tidak menutup kemungkinan bagi pemilik bank BUMN, swasta nasional bahkan pihak asing sekalipun untuk membuka cabang syari'ahnya di Indonesia. Dengan terbukanya kesempatan ini jelas akan memperbesar peluang transaksi keuangan di dunia perbankan Indonesia, terutama bila terjalin hubungan kerjasama di antara bank-bank syari'ah.

Signifikansi perbankan syari'ah dalam konstalasi perekonomian Indonesia adalah turut serta dalam bentuk modal berimbang dari usaha-usaha produktif di Bisnis Vol 6, No.1, Juni 2018 


\section{Selamet Syaifuddin}

negara-negara anggota, menanam modal pada proyek prasarana ekonomi dan sosial di negara-negara anggota dengan cara penyertaan; memberikan pinjaman pada sektor swasta dan negara untuk membiayai proyek-proyek usaha dan program-program yang produktif; membentuk dan mengoperasikan dana khusus untuk keperluan-keperluan khusus, termasuk dana sosial untuk membantu masyarakat muslim yang berada di luar anggota; menyediakan bantuan teknis kepada negara-negara anggota dan memajukan perdagangan internasional; melaksanakan penelitian agar kegiatan ekonomi, keuangan dan perbankan di negara-negara Islam dapat disesuaikan dengan ketentuan syari'ah; bank mencoba mencari sebuah rasio yang layak untuk mempertahankan suatu perbandingan yang cocok antara penanaman modal yang diberikan kepada negara-negara anggota; bank akan mempertahankan hak dan kebebasannya untuk menjual saham penyertaannya; berusaha mempertahankan suatu keanekaragaman yang wajar dalam penanaman modal; memungut suatu biaya atas jasa-jasanya guna menutupi ongkos administrasi 
Membaca Kilas Regulasi Perekonomian

\section{DAFTAR PUSTAKA}

CSIS, Himpunan Peraturan Perundang-undangan Paket Kebijakan Keuangan, Moneter, dan Perbankan 27 Oktober 1988. tidak diterbitkan, hlm. i-vi 4.

Djiwandono, J. Soedrajad. 2001. Mengelola Bank Indonesia dalam Masa Krisis, Jakarta: LP3ES.

H. Kara, Muslimin. 2005. Bank Syari'ah Di Indonesia, Analisis Kebijakan Pemerintah Indonesia Terhadap Perbankan Syari'ah, Yogyakarta: UII Press.

Indrawati, Sri Mulyani. 1999. "Prospek Ekonomi Pasca Era Transformasi Reformasi" dalam Faisal Siagian, Reformasi BUMN dalam Perspektif Krisis Ekonomi Makro, Jakarta: Pusat Reformasi dan Pengembangan BUMN.

Nasution, Anwar. 1994. Pembangunan dan Demokratisasi Sistem Ekonomi Indonesia, dalam Elza Peldi Taher (Editor), Demokratisasi Politik, Budaya dan Ekonomi: Pengalaman Indonesia Masa Orde Baru, Jakarta: Yayasan Paramadina.

Perwataatmadja, Karnaen A. 1996. Membumikan Ekonomi Islam di Indonesia, Depok: Usaha Kami.

Rahardjo, Dawam. 1999. Islam dan Tranformasi Sosial-Ekonomi, Jakarta: LSAF.

Sarkaniputra,Murasa. 2011. Parameter Akad dan Pengawasan dalam Transaksi Syari'ah, Makalah disajikan dalam Seminar Akad dan Pengawasan dalam Transaksi Ekonomi Syari'ah tanggai 23-24 Juli 2011. 